\title{
David Oliver: What should senior doctors be paid?
}

\author{
David Oliver consultant in geriatrics and acute general medicine, Berkshire
}

The English health secretary, Jeremy Hunt, claimed in his " 25 year vision" that the average wage for a hospital consultant was $£ 118000$ ( $€ 167000 ; \$ 184000$ ) a year, putting us in "the top $2 \%$ income bracket."1

This made for a good soundbite, but Hunt's speech was heavy with spin to sell changes in the consultant contract. Portraying doctors as overpaid, lazy, or Luddite plays to certain sections of the media and the public during austerity.

In fact, a consultant's starting salary in England is $£ 75$ 000, rising incrementally to $£ 101000$ after 19 years. ${ }^{2}$ Doctors generally become consultants in their mid-30s, so they're already late in their career by the time they hit the top of the scale. Many work well beyond their contracted hours for no more pay. ${ }^{3}$

Most consultants know that we are well remunerated for what is generally a fulfilling and privileged career in a job we freely chose. Despite recent increases to contributions, a higher retirement age, and reduced settlements, our pensions would be envied by many. Some consultants think it valid to compare their pay with levels in private industry or the fees they'd get in private healthcare; I don't. Instead, I'll start from the basis that we are senior salaried public servants, rather than contractors selling our skills to the NHS.

So, what should we actually be paid? We spend five or six years at a competitive entry medical school. We do a decade's postgraduate training (long by international comparison), with heavy clinical workload, rigorous competency assessments, entry and exit exams, and additional degrees or doctorates throughout. On becoming consultants, we take responsibility for large numbers of patients in many settings. Our decisions have crucial human consequences that matter more than in many graduate professions. The job comes with big personal pressure. Consultants in medical management roles are often responsible for multimillion pound budgets and manage many senior colleagues for little additional pay.

Comparing apples and oranges is hard, but let's try. Police chief superintendents start on $£ 78000$ before overtime, ${ }^{4}$ army colonels start on $£ 84000,{ }^{5}$ and salaries for both rise incrementally. Judges start on around $£ 100000 .{ }^{6}$ And senior civil servants in pay band 1A start on $£ 67000$, progressing incrementally to $£ 128000$. So, doctors get more or less the going rate for senior, experienced, salaried public servants.

Specialties such as emergency medicine, ${ }^{8}$ as well as general practice, ${ }^{9}$ are struggling to recruit or retain doctors even with the current pay scales, and NHS clinicians had a pay freeze throughout the last parliament, with a $1 \%$ rise proposed for this one. ${ }^{10} \mathrm{I}$ don't expect sympathy for well paid professionals in high status jobs-but whipping up outrage is a cheap trick that does nothing to help the real problems affecting our workforce.

Competing interests: I have read and understood the BMJ policy on declaration of interests. I am a salaried NHS doctor who has never done private practice and a member of the BMA.

Provenance and peer review: Commissioned; not externally peer reviewed.

Hunt J. Making healthcare more human centred and not system centred (speech). King's Fund 16 July 2015. www.gov.uk/government/speeches/making-healthcare-more-humancentred-and-not-system-centred.

2 BMA. Pay scales for consultants in England 2015. http://bma.org.uk/practical-support-atwork/pay-fees-allowances/pay-scales/consultants-england.

3 Flynn P. Speech to the BMA Consultants Conference 2014. http://bma.org.uk/workingfor-change/negotiating-for-the-profession/bma-consultants-committee/paul-flynn-speech.

4 Police Superintendents' Association of England and Wales. Superintending pay scales. 16 May 2014. www.policesupers.com/superintending-pay-scales/.

5 Ministry of Defence. Army officer rates of pay-April 2015. www.army.mod.uk/documents/ general/Rates_of_Pay_Officer_2015.pdf.

6 Ministry of Justice. Ministry of Justice judicial salaries from 1 April 2015. www.gov.uk government/uploads/system/uploads/attachment_data/file/419123/judicial-salaries-1-april2015.pdf

7 House of Commons Library. Civil servants' and MPs' salaries. 16 July 2013. http:// researchbriefings.files.parliament.uk/documents/SN06689/SN06689.pdf.

8 Campbell D. A\&E departments face crisis as staff burn out and consultants move abroad. Guardian 2013 Oct 8. www.theguardian.com/society/2013/oct/08/emergency-departmentsface-staff-crisis.

9 Dayan M, Arora S, Rosen R, Curry N. Is general practice in crisis? Nuffield Trust 2014. www.nuffieldtrust.org.uk/sites/files/nuffield/publication/general_practice_in_crisis_3.pdf.

10 Dudman J. Public services staff face four more years of pay pain. Guardian 2015 July 8. www.theguardian.com/public-leaders-network/2015/jul/08/pay-cap-public-servants-budget2015.

Cite this as: BMJ 2015;351:h4373

๑) BMJ Publishing Group Ltd 2015 